Portland State University

PDXScholar

7-8-1996

\title{
La Perspectiva Indigenista y Neoindifenista de Huasipungo y Porque se Fueron las Garzas
}

\author{
Laura Bergman \\ Portland State University
}

Follow this and additional works at: https://pdxscholar.library.pdx.edu/open_access_etds

Part of the Spanish and Portuguese Language and Literature Commons Let us know how access to this document benefits you.

\section{Recommended Citation}

Bergman, Laura, "La Perspectiva Indigenista y Neoindifenista de Huasipungo y Porque se Fueron las Garzas" (1996). Dissertations and Theses. Paper 4929.

https://doi.org/10.15760/etd.6805

This Thesis is brought to you for free and open access. It has been accepted for inclusion in Dissertations and Theses by an authorized administrator of PDXScholar. Please contact us if we can make this document more accessible: pdxscholar@pdx.edu. 
THESIS APPROVAL

The abstract and thesis of Laura Bergman for the Master of Arts in Spanish were presented July 8,1996 , and accepted by the thesis committee and the department.

COMMITTEE APPROVALS:

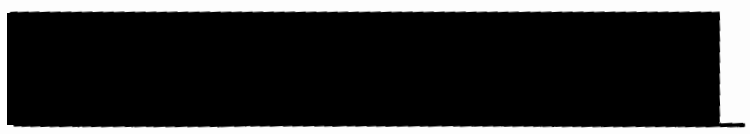

Earl L. Rees, Chair

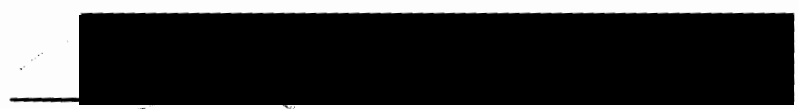

Frank Vecchio

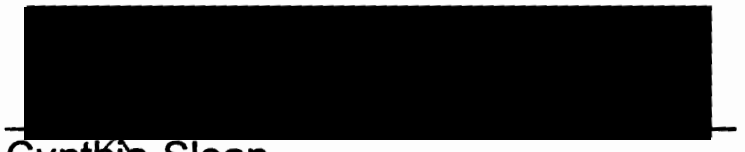

Cynthis Sloan

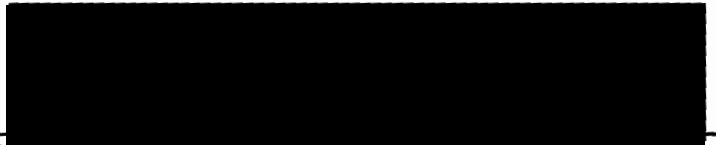

Maria Wilson-Figueroa

Representative of the Office of Graduate Studies

DEPARTMENT APPROVAL:

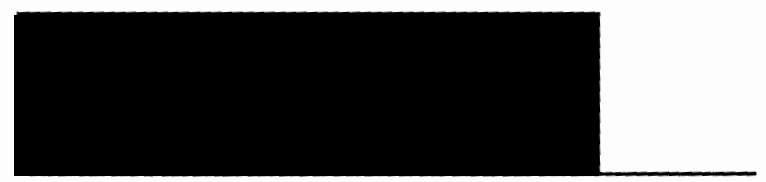

Louis Elteto, Chair

Department of Foreign Languages and Literatures

ACCEPTED FOR PORTLAND STATE UNIVERSITY BY THE LIBRARY

by on

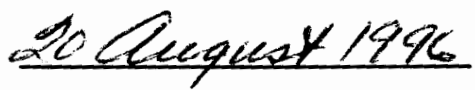




\section{ABSTRACT}

An abstract of the thesis of Laura Bergman for the Master of Arts in Spanish presented July 8, 1996.

\section{Title: LA PERSPECTIVA INDIGENISTA Y NEOINDIGENISTA DE HUASIPUNGO Y PORQUÉ SE FUERON LAS GARZAS}

El indio siempre ha sido un objeto importante en la literatura latinoamericana. Este referente indígena ha pasado por un proceso evolutivo: el indianista y el neoindigenista (Marcos 445). Dentro del último se desarrolla una tendencia llamada neoindigenismo (Rodríguez-Luis 46).

El propósito de esta tesis es analizar la perspectiva indigenista y neoindigenista de las novelas Huasipungo y Porqué se fueron las garzas por medio del tratamiento de sus protagonistas y del lenguaje como instrumento de la representación auténtica de las culturas que se describen en estas obras. EI enfoque en Huasipungo es más institucional que el de Porqué se fueron las garzas, el cual se preocupa por el mejoramiento de toda la sociedad, pero al mismo tiempo, le da importancia a la esencia cultural indígena que es parte esencial de los individuos. Este estudio está divido en cuatro partes: la humanidad del indígena en la estructura social, exterioridad e interioridad de los protagonistas, ausencia histórica y búsqueda ancestral, y el uso del lenguaje estándar y popular. 


\title{
LA PERSPECTIVA INDIGENISTA Y NEOINDIGENISTA \\ DE HUASIPUNGO Y PORQUÉ SE FUERON LAS GARZAS
}

by

\section{LAURA BERGMAN}

\section{A thesis submitted in partial fulfillment of the} requirements for the degree of

\author{
MASTER OF ARTS \\ in \\ SPANISH
}

PORTLAND STATE UNIVERSITY

1996 
TABLA DE CONTENIDOS

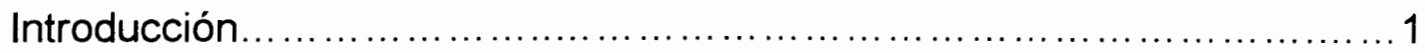

LA HUMANIDAD DEL INDÍGENA EN LA ESTRUCTURA SOCIAL ...........6

Enfoque institucional en Huasipungo .............................6

Enfoque cultural en Porqué se fueron las garzas ...................16

EXTERIORIDAD E INTERIORIDAD DE LOS PROTAGONISTAS ..........24

La exterioridad de Andrés Chiliquinga ............................24

La interioridad de Andrés Tupatauchi .............................29

AUSENCIA HISTÓRICA Y BÚSQUEDA ANCESTRAL ......................36

EL USO DEL LENGUAJE ESTÁNDAR Y POPULAR .......................41

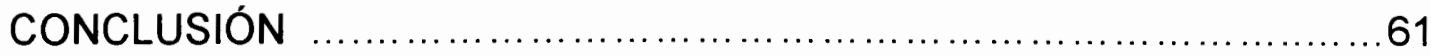

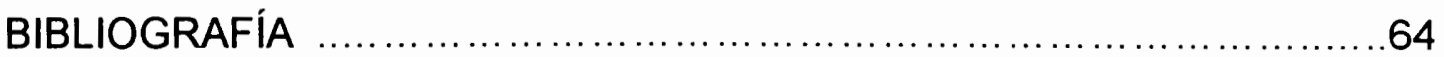




\section{LA PERSPECTIVA INDIGENISTA Y NEOINDIGENISTA DE HUASIPUNGO Y PORQUÉ SE FUERON LAS GARZAS}

\section{INTRODUCCIÓN}

Un tema muy conocido en la literatura hispanoamericana es el del indio. Este referente indígena ha pasado por un proceso evolutivo en el cual se distinguen dos períodos: el "indianista" y el "indigenista" (Marcos 445). Dentro del indigenismo, se desarrolla, además, una tendencia llamada "neoindigenismo" (Rodríguez-Luis 46). El indianismo llegó a un alto grado de popularidad en la época romántica, en la cual el indio fue tratado como una figura decorativa. Este "movimiento nos dejó una visión deformada del indio -- de espaldas a su trágica situación social, por la tendencia a la idealización y al aprovechamiento de lo pintoresco y folklórico" (Gómez-Gil 611). Hay dos obras ejemplares de este período: Guatimozín, último emperador de México (1846), de la escritora cubana Gertrudis Gómez de Avellaneda, y Cumandá (1871) del ecuatoriano Juan León Mera.

La etapa moderna en cuanto a la prosa sobre el indígena, se inicia con la obra Aves sin nido (1889), de la peruana Clorinda Matto de Turner. Con esta 
novela, la autora da el primer impulso al movimiento indigenista por la audacia con que denuncia las condiciones de servidumbre y explotación que sufre la población indígena. El indio aquí deja de ser una figura exótica, para convertirse en una persona de "carne y hueso" (Chang-Rodríguez 122).

Siguiendo los pasos de Matto de Turner, muchos escritores comenzaron a interesarse en los problemas económicos y sociales del indio. Michael $\mathrm{H}$. Handelsman considera que es precisamente "este interés sociológico como tema predominante junto a su correspondiente mensaje de reivindicación de las comunidades indigenas [que] forman la esencia del indigenismo" (59). Indigenismo es la "tendencia que dentro del realismo hispanoamericano describe al indígena como una persona de carne y hueso a la vez que denuncia el estado de opresión en que se encuentra" (Chang-Rodríguez 539). Orlando Gómez-Gil añade que en las novelas indigenistas "los abusos, sufrimientos y estado de servidumbre y explotación a que están sometidos los indios por los patrones o gamonales ${ }^{1}$ blancos y ricos [se realizan] con la protección de las autoridades y el clero" (613). El indigenismo "Considera al indio como un problema económico y social", expone la vida angustiosa del indio en toda su crudeza, asi como también "la avaricia, la brutalidad y la explotación" por parte de una sociedad feudal sin escrúpulos (Gómez-Gil 613). Por esto, la narrativa indigenista en general, pero la andina, en particular, se convierte en una 
literatura de protesta social, de literatura comprometida "que no siempre es creación estética" (Cometa 12). Su propósito es concientizar al lector y a quienes puedan contribuir a solucionar este gran problema social. Raza de bronce (1919) del boliviano Alcides Arguedas y Huasipungo (1934) del ecuatoriano Jorge Icaza son obras representativas de este grupo. Dos acontecimientos importantes influencian a estos escritores: el triunfo de la Revolución Mexicana que se inicia en 1910 y que representa "el primer grito de justicia social en América y la rusa, que abre el camino para una literatura impregnada de intensa emoción social" (Cometta 12).

A partir de los años cuarentas, con la culminación de El mundo es ancho y ajeno de Ciro Alegría y Yaguar fiesta de José María Arguedas, ambas de 1941, el indigenismo decae en su capacidad creativa. Luego, en la década de los '50, con obras como Ríos profundos (1958) de José María Arguedas, Oficio de Tinieblas (1962) de Rosario Castellanos y Porqué se fueron las garzas (1979) de Gustavo Alfredo Jácome, entre otras, el neoindigenismo se define con la inclusión de ciertas técnicas narrativas como la descripción de los personajes desde su interior, la multiplicidad de puntos de vista, ruptura del tiempo cronológico, los diversos niveles de la realidad simultánea, la yuxtaposición de acontecimientos reales e imaginarios, un lenguaje más representativo del referente, la intensificación del lirismo y la participación activa del lec- 
tor (Chang-Rodríguez 304). Se considera, además, la ampliación del espacio de la representación narrativa, en el que se incluye no sólo la problemática indígena aislada, sino también la sociedad en conjunto como consecuencia de los cambios sociales y económicos.

Uno de estos cambios es la eliminación del feudalismo que causa la migración del indio a las ciudades, las cuales se desenvuelven dentro de la economía capitalista. Este proceso migratorio provoca en el indio una lucha existencial al tratar de integrarse al mundo moderno lleno de prejuicios y presiones, en el cual termina marginado (Handelsman 66). Por lo expuesto se observa que la visión del indio en el indigenismo aparece parcialmente ajena a un humanitarismo genuino porque pone "Mayor énfasis en la descripción de la condición social exterior del indio que en la pintura de su mundo anímico" (Gómez-Gil 612). A diferencia del indigenismo, cuyo punto de vista es más institucional, como la abolición del feudalismo, la aspiración a la recuperación de la tierra para devolvérsela al indio y así conseguir su reivindicación, el neoindigenismo se empeña por buscar el mejoramiento de la sociedad en conjunto: blancos, indios y mestizos. Además trata de explorar el fondo del indio y sus raíces culturales para buscar las bases de la única autenticidad posible que salvará a los pueblos indígenas (Julio Rodríguez-Luis 46).

Academia Española,1984. En los paises andinos, gamonal tiene una connotación peyorativa. 
El propósito de este estudio es analizar el punto de vista indigenista de Huasipungo y el neoindigenista de Porqué se fueron las garzas por medio del tratamiento de sus protagonistas y del lenguaje como instrumento de la representación auténtica de las culturas que se describen en estas obras. El enfoque en Huasipungo es más institucional que el de Porqué se fueron las garzas, el cual se preocupa por el mejoramiento de toda la sociedad, pero al mismo tiempo, le da importancia a la esencia cultural indígena que es parte esencial de los individuos. 


\section{LA HUMANIDAD DEL INDÍGENA EN LA ESTRUCTURA SOCIAL}

\section{Enfoque institucional en Huasipungo}

Superficialmente, el indigenismo responde a una estructura social sencilla formada por dos estratos: el de los terratenientes y el de los indios. Los primeros ejercen absoluto control sobre la comunidad indigena y sobre la tierra. Los segundos aparecen despojados de todos sus tierras y sus derechos y reducidos a la servidumbre. En realidad, se trata de una organización social compleja porque dentro de este sistema operan también las autoridades y el clero como cómplices en la explotación del indio. Además, las compañías extranjeras auspiciadas por el capitalismo contribuyen a desarraigar al indio de sus tierras para dar paso a la expansión imperialista. La tensión de Huasipungo ${ }^{2}$ surge, precisamente, de la agresión capitalista que provoca la expulsión de los indios de sus huasipungos (Cueva 177).

En Huasipungo el plan del latifundista Pereira es expandir el área de su hacienda Cuchitambo con la compra de los bosques de Filocorrales y Guamaní, construir un carretero que cruce esta hacienda, asi las tierras habrán ganado de valor, para luego venderlas a una compañía extranjera, explotadora de madera (Gómez-Gil 615). La ambición del terrateniente va más

\footnotetext{
2 “Huasipungo: Huasi: casa; pungo: puerta. Parcela de tierra que otorga el dueño de la
} 
allá de la expansión de sus tierras. Le interesa, además, obtener más indios para asegurar la mano de obra gratis para la construcción del camino a su hacienda. Su tío, don Julio Pereira, un empresario muy astuto, le confirma que no hay ningún problema porque: "Con los bosques quedarán los indios. Toda propiedad rural se compra o se vende con sus peones" (Icaza 9). En esta empresa, a la que Pereira y sus secuaces, el cura y el teniente político, le dan el carácter social, obligarán a los indios a trabajar en mingas ${ }^{3}$ a fuerza de látigo y grandes dosis de alcohol (Gómez-Gil 615). Las condiciones de trabajo para abrir el camino son de lo más precarias: terreno pantanoso, llovizna constante, viento helado del páramo, escasa alimentación, pero derroche de aguardiente (alcohol) y látigo. Al cabo de algunos días de trabajo en estas condiciones, muchos indios caen enfermos, debilitados por el soroche ${ }^{4}$ y algunos hasta mueren. Pero el indio no puede dejar de trabajar aunque esté enfermo, agonizante. El capataz puede curarlo todo, por eso hace alarde:

Yo le he curar no más - concluyó Rodríguez dándose importancia... Claro. Aquí tengo el acial que es taita y mama para las enfermedades de los runas — contestó el cholo tuerto exhibiendo con sádico orgullo el látigo que colgaba de su mano...

hacienda a la familia india por parte de su trabajo diario" (Icaza 159).

${ }^{3}$ "Minga: Trabajo colectivo. Vieja costumbre heredada del Incario" (Icaza 160).

4 "Soroche: enfermedad de los páramos por la altura" (Icaza 161). 
Cuando todo estuvo a gusto y sabor del tuerto —el indio medio desnudo, amarrado al tronco-, el acial silbó como una víbora varias veces sobre el enfermo... Veamos si hay soroche que resista, carajo... Bueno. Para mejor efecto de la calentadita que le propiné al indio sería aconsejado darle una copa doble de puro (Icaza 78-79).

El valor literario de Icaza reside en saber pintar estas situaciones vívidamente y "con gran economía verbal... Nos narra su cuento con golpes rápidos y demoledores" dice Alarcón (54). Además, la destreza artística de Icaza está en haber sabido crear hábilmente del relato de la construcción del camino, el asunto de Huasipungo. Refiriéndose a este talento artístico, Carleton Beals, después de calificar a Icaza de "uno de los más vigorosos entre los novelistas recientes, dice: "la relación de la construcción del camino es una composición de insuperable habilidad artística y de intenso dramatismo" (citado en Alarcón 54).

Los escritores indigenistas se enfrentan en esta época con otro enemigo a más de los expoliadores nacionales, la incursión de compañias extranjeras capitalistas que comienzan a cambiar las antiguas relaciones de producción y de trabajo. Por ejemplo, la construcción del camino que llega hasta la hacienda de Pereira beneficia no solamente al terrateniente y a sus socios extranjeros, explotadores de madera, pero también al cura avariento 
quien sabe aprovechar la bondad de un buen carretero para hacer transitar su "camión de transporte de carga y autobús para pasajeros" comprados con las buenas utilidades que le dejan las limosnas, los responsos, extraídos de los mismos indios (Icaza 105). El servicio de estos vehículos, poco a poco iba dejando a los arrieros de la comarca sin trabajo y pronto quedaron sumidos en mayor pobreza y angustia que antes de la existencia del carretero.

En cambio, para el terrateniente, sus problemas financieros y técnicos pueden resolverlos fácilmente Mr. Chapy, "Un caballero de grandes recursos, de extraordinarias posibilidades, de millonarias conexiones en el extranjero. Un gringo ${ }^{5}$ de esos que mueven el mundo con un dedo" (Icaza 7). Pereira sabía que su salvación económica estaba en manos de Mr. Chapy; por lo tanto, tenía que proveer todas las comodidades necesarias a los extranjeros aunque aquello pudiera significar "limpiar de huasipungos las orillas del río...para construir las casas de habitación para ellos", para los gringos (Icaza 8).

Esta preferencia al extranjero y desprecio al indio, revive una vez más la filosofía malinchista ${ }^{6}$ que se repite frecuentemente en toda la historia de América Latina. Doña Marina como la bautizaron los españoles a la Malinche, fue la amante indigena de Hernán Cortés, el conquistador del imperio Azteca-

\footnotetext{
${ }^{5}$ La palabra gringo, en América Latina tiene una connotación peyorativa.

${ }^{6}$ Para una completa explicación del Malinchismo, refiérase a El laberinto de la soledad, en particular al capítulo IV p.59-80.
} 
Mexica. Ella se ha convertido en el símbolo de la traición; por eso no es "extraña la maldición que pesa contra la Malinche. De ahí el éxito del adjetivo despectivo "malinchista"...para denunciar a todos los contagiados por tendencias extranjerizantes" (Paz 78).

En particular, la figura de Pereira, el latifundista codicioso y lascivo, nos recuerda la del conquistador español -- el modelo perfecto -- de los señores feudales, de los gamonales (caciques), hacendados, políticos, etc., "los hijos de la chingada: los extranjeros, los malos mexicanos, nuestros enemigos, nuestros rivales", como los llama Octavio Paz en El laberinto de la soledad $(68,74)$. Como se ha podido observar, el autor de Huasipungo protesta enérgicamente por la intervención de los extranjeros expansionistas y por la ambición del terrateniente que "facilita los planes del imperialismo" (Cometa 12).

Al terrateniente le secundan el caudillo político y el cura en la explotación del indio. El primero no vacila en emplear la fuerza contra la población indígena para conseguir una situación privilegiada y lucrar de ella y el segundo mantiene al indio en un constante estado de ignorancia, atemorizándolo con los posibles castigos de un dios justiciero y vengativo con el fin de explotarlo. Si los indios mueren en los trabajos forzados o en las mingas, o las indias son violadas, nadie vela por ellos; la justicia no hizo para ellos sino para los poderosos. Si tratan de protestar por tanto abuso recibido, entonces sí las autorida- 
des actúan inmediatamente para sofocar las protestas indigenas. Por ejemplo, el teniente político, Jacinto Quintana es un colaborador asiduo del terrateniente Pereira. Su trabajo es cumplir y hacer cumplir la voluntad de aquel para asegurar su empleo, por eso, está de acuerdo en todo lo que Pereira dice:

- Los runas verán con sus propios ojos que el robo, la pereza, la suciedad, la falta de respeto a las cosas del amo, sólo conducen a la sanción ejemplar, al castigo, a las torturas del látigo... - Lo que usted diga, pes. Estos indios perros le van a quitar la existencia. ¿Dónde un patrón así? (Icaza 139).

Quintana, el teniente político, siempre está presto a colaborar con el latifundista. El fue el encargado de suministrarle los azotes a Andrés Chiliquinga cuando fue condenado al flagelo en público por haber robado una vaca del patrón. Anonadado por la muerte de su mujer, desesperado, sin dinero y sin ninguna posibilidad de conseguirlo honradamente, Chiliquinga se vio en la necesidad de robar para obtener dinero y poder pagar al cura avaro que se negaba dar sepultura cristiana a Cunshi, su mujer: "iTráiganle acá! -ordenó Jacinto Quintana, que oficiaba el acto de maestros de ceremonias" (Icaza 139). Los policias arrastraron al ladrón hasta los pies de Quintana. Después de desnudarlo hasta el ombligo, le ataron con una cuerda por los pulgares sobre una horqueta. Ya en posición adecuada, "él teniente político... a un gesto imperativo de don Alfonso Pereira -- quien presidía desde 
el corredor de la casa aquel 'tribunal de justicia'-- flageló al indio" sin piedad, hasta dejarlo semiconsciente (Icaza 140).

Este es uno de los cuadros más conmovedores de la novela, pero la protesta de Icaza no es menos impresionante por el estilo vivo y preciso con que describe el trato brutal y aniquilador que recibe Chiliquinga. Si el ejército puede avasallar a los indios indefensos que quedan a la intemperie después de ser despojados intempestivamente de sus huasipungos, Icaza también puede y sabe someter a las autoridades a su dictamen, poniendo al descubierto la fuerza atroz con que arremeten a los indios. Además, pinta con hondo sentimiento el estado de dolor y aturdimiento que experimentan las indias que sin tener suficiente tiempo tratan de recoger la cotona, el rebozo, la faja del guagua o las cucharas de palo, todo al mismo tiempo, mientras el teniente político y los policías derribaban las chozas armados con picas, barras y palas, y gritaban: “-¡Fuera!... Esta tierra necesita el patrón... ¡Fuera todos!...”. Angustiados, pero indignados a la vez, los indios, sin poder resignarse a la idea que ya no les quedaba nada, ni siquiera "ese pedazo de tierra que hasta hace unos momentos le creia[n] suyo", se rebelan y como con una venganza contenida, quieren demostrar sus fuerzas (Icaza 145-46). Tratan de defender lo suyo "con puños, piedras, palos y herramientas, pero rápidamente sucumben a "las balas de los fusiles y las balas de las ametralladoras... Cazaron y mataron a los rebeldes con la misma diligencia, 
con el mismo gesto de asco y repugnancia con el cual hubieran aplastado bichos venenosos... ¡Qué mueran todos! Sí... -Que se acabe con ellos como hicieron otros pueblos más civilizados" (Icaza 153-154). Icaza acaba también de aplastar al poderoso con ese lenguaje fulminante que es su arsenal artístico. Revela claramente, sin titubeos, la violencia y la eficacia con que actúan las autoridades cuando se trata de sofocar a los indígenas.

Por último, el cura, el mejor manipulador del indio, lo mantiene embotado con el fin de extorsionarlo. Icaza no le confiere nombre al cura; no se lo merece. No es cuestión de tipificación de personajes, como se le ha acusado. Puede ser cualquier clérigo que se aproveche de la religión para explotar a los indígenas. Por ejemplo, Tancredo Gualacoto, había sido designado prioste ${ }^{7}$ de una fiesta de acción de gracias. Se le conocía a Gualacoto como indio rico porque tenía una vaca, algunos pollos y otros pequeños animales más. Como prioste, debía suministrar la comida y la bebida para la fiesta. Además, debía entregar al cura cien sucres por derechos de la misa. Ante la imposibilidad de reunir esa suma, Gualacoto y sus amigos le pidieron cura una rebaja. Indignado éste le contestó:

— ¿Cómo puedes imaginarte...que en una cosa tan grande, de tanta devoción, la Virgen se va a contentar con una misa de a

7 Prioste, en el Ecuador, es la persona elegida a cuya cuenta corren todos los gastos de una fiesta religiosa católica. 
perro? ¡No¡ ¡Imposible! ¡De ninguna manera!

-Pero...Nu tengu, pes...

-Taiticuuu -- suplicó el coro.

— ¡Miserable! Y no debes mesquinar más porque la Virgen puede

calentarse. $Y$ una vez caliente te puede mandar un castigo.

-iNu tengu, pes!

- Para beber si tienes, indio corrompido... Pero para venerar a la Santísima Virgen te haces el tonto. Por miserables cien sucres has caído en pecado. Dios es testigo de tu tacañería. El...El nos está viendo...Cuando te mueras te cobrará bien cobrado (Icaza $98)^{8}$

La crítica de lcaza sobre el clero es mordaz y directa como el resto de su denuncia. Inviste al sotanudo de tal sagacidad que rebasa toda consideración cristiana y aún humana. No solamente todos los actos religiosos tienen un precio, derechos de misa, derechos de sepultura, entre otros, pero el indio tiene que pagarlos como sea. El cura mantenía a los indios hipnotizados de miedo. Les repetía una y otra vez que a Dios no se le puede negar nada porque vendrán castigos.

He aquí el grupo de castas sociales privilegiadas responsable de la

\footnotetext{
${ }^{8}$ Para una explicación del cambio de vocales en el lenguaje popular, ver nota 16.

${ }^{9}$ Palabra despectiva que usa el autor para designar al cura párroco.
} 
miseria del indio. En Huasipungo como en el resto del indigenismo no puede darse énfasis a otra perspectiva que a la de la sociedad como institución, porque el problema no es el indio ni su cultura indígena en sí, sino la sociedad que le ha privado de sus valores humanos impidiendo "al grupo indígena [realizar] sin dificultad sus valores, en medio de la secular depredación ejercida por el latifundista feudal, el cura y el resto del aparato moral y materialmente represivo" (Cueva 179).

Frente a esta situación ignominiosa del indio, Icaza asume la responsabilidad de denunciar sin miedo la opresión y la crueldad con que es tratado el indio. Lucha con vehemencia, al igual que sus contemporáneos por desarmar estas fuerzas socioeconómicas feudales para salvar al indio del estado de paria en que le mantiene esta sociedad. Esta injusticia social no es un problema reciente; la masa indígena ha sido su víctima desde el tiempo de la Conquista española. Tan pronto como dominaron al indio, los españoles se apoderaron de los tesoros del Inca (jefe), de sus tierras y de dueños naturales, los indígenas. Los conquistadores españoles "no se posesionaron de las tierras para cultivarlas, ni de los indios para culturizarles, sino para explotar la tierra, por medio de los indios y a los indios por medio de la tierra" se lamenta Segundo Maiguashca ${ }^{10}(18)$.

\footnotetext{
${ }^{10}$ Maiguashca es indio ecuatoriano, autor de El indio cerebro y corazón de América. "El libro del Dr. Maiguashca tiene una significación muy singular, pues contiene una investigación
} 


\section{Enfoque cultural en Porqué se fueron las garzas}

Partiendo nuevamente del vínculo innegable que existe entre la situación política, social y económica y la creación literaria, es necesario recordar que mientras a los indígenas de Huasipungo les afecta la realidad sociológica de la primera década de 1900, los personajes de Porqué se fueron las garzas, cincuenta años más tarde, se encuentran en una sociedad que:

pese a la persistencia del 'subdesarrollo' y la 'dependencia'... ha sufrido importantes cambios... (desarrollo indudable del modo de producción capitalista), y que estos cambios... se han traducido por sendas transformaciones en el quehacer literario y en la concepción de la literatura (Cueva 162).

Si bien nos encontramos en una época de semicapitalismo, se observa poco cambio en la estructura social. Todavía el indio se encuentra en la base del estrato social y económico, presa de muchos prejuicios y marginado del resto de la sociedad (Cueva 167). Porque el indio no sido rescatado todavía, los escritores indigenistas continúan denunciando estas anomalias con el afán de liberarlo de su postración social y económica. Pero ahora, estos escritores se dan cuenta que es necesario establecer una relación más íntima con su referente indigena; aprovechan el "proceso de interiorización que, por lo 
general, se ha logrado con la asimilación de técnicas modernas (el monólogo interior, el fluir de la consciencia, lo onírico)..."; además, el indio es observado desde diferentes planos y se lo hace hablar en un lenguaje más natural y propio de este referente (Handelsman 60). Así surge la novela neoindigenista, con una perspectiva más humana y consciente de los valores humanos indígenas y además llena de autenticidad, de la cual Porqué se fueron las garzas es una representativa. El neoindigenismo concibe la reivindicación del indio y su incorporación a la nacionalidad como resultado del cambio social y económico. En el indigenismo de Jácome se distinguen algunos de estos cambios. Quinchibuela, el lugar natal y de residencia del protagonista de Porqué se fueron las garzas, es una parroquia urbana, económicamente muy adelantada, gracias a la habilidad artesanal y emprendedora de sus habitantes. Estos se ven obligados a aprender el español para poder comunicarse en sus actividades comerciales, aunque reservan el quichua, su lengua materna, para hablar entre ellos. Producto de estos cambios es Andrés Tupatauchi, cuyo éxito se basa en su educación, a pesar que esto le acarrea problemas de discriminación en su vida diaria y en las organizaciones a las que pertenece para reconquistar sus derechos y la igualdad del indio en la sociedad.

Con el desmantelamiento del sistema feudal, comienza la migración del indio a la ciudad, y con ella cambios y adaptaciones de este nuevo ambiente. 
El protagonista de Porqué se fueron las garzas, Andrés Tupatauchi, vive en una área urbana, muy progresista donde muchos de sus moradores son tejedores hábiles de profesión, de lo cual está muy orgulloso. Su educación le lleva a conseguir una beca para hacer estudios posgraduados en una universidad de los Estados Unidos. Andrés regresa a su tierra casado con una gringa, después de siete años y encuentra que: "Quinchibuela había cambiado. Había perdido su inocencia. Se le notaba en los ojos,,.. en los callejones ensanchados por donde había comenzado a transitar la jactancia de los naturales motorizados con sus propias camionetas y automóviles" (Jácome 39). Andrés también ha cambiado. Se le nota en su inseguridad. Oscila entre dos mundos diferentes: el de los blancos y mestizos en el que no es aceptado pero al cual trata de integrarse desesperadamente, y el suyo, el indígena, que ahora lo desprecia porque "Ha vuelto vestido como natural mismo, igualito por fuera está, pero cambiaaado por dentro...trucarishca, cambiado, dado la vuelta, como bolsillo nomás" (Jácome 41).

Sacoto dice que Andrés es un "protagonista continuamente acosado por mil facetas de la cultura moderna en contrapunto con sus raíces ancestrales..." (Algunas 250). Mientras investiga las fuentes de su origen, asunto que le mantiene constantemente preocupado, encuentra, por rara coincidencia, que dos libros viejos habian quedado rezagados en la hacienda de Quinchibuela, uno de 1749 y otro de 1761 . Estos contenian listas interminables de cuentas 
de obraje, ${ }^{11}$ como cantidad de varas de material hecho y entregado por cada tejedor, sus anticipos y sus deudas. Entre los nombres, de los tejedores que figuraban en las listas, Andrés encontró nombres de algunos Topatauches, lo que le apenó gravemente porque esto explicaba como sus antecesores reales habian terminado en la esclavitud. "Pero había un consuelo: de ese obraje había salido la actual habilidad de los tejedores de Quinchibuela" (Jácome 169). De esto estaba orgulloso, pero al mismo tiempo experimentó coraje y rebeldía al recordar la historia de los obrajes. Sintió una especie de rencor y de pronto decidió hacer algo y se preguntó a sí mismo: "Has pensado bien, Andrés Tupatauchi. Sería una especie de desquite. Una manera de vengar a tantas víctimas, en tantos siglos. Sí, antes que te pasen las iras" (Jácome 171). Andrés actúa diligentemente y en corto tiempo obtiene la adjudicación legal de treinta hectáreas que pertenecian a la hacienda Quinchibuela. De esta manera, la escuela de la cual él es el rector, cuenta con un edificio nuevo para

\footnotetext{
11 "La habilidad artesanal de los indios; el empleo de telares y herramientas primitivos; el aprovechamiento de fibras nativas y las nuevas, traídas por los conquistadores...se entregaron familias indígenas a los colonizadores, para que los consagren a la actividad textil. En construcciones rústicas, húmedas, sin ventilación, llamadas batanes, se enceraban a esos obreros para labores de tiempo mientras duraba la claridad del día. Colaboraban en las faenas mujeres y niños, cuando era necesario. Lavaban, cardaban, hilaban y tejían las fibras, bajo vigilancia severa de capataces, con látigos para castigar y con normas carcelarias; al medio día tenían un frugal alimento; a veces, rezos y prácticas religiosas casi mecánicos, que estaban a cargo de doctrineros." Rubio Orbe, Gonzalo. Los indios ecuatorianos: Evolución histórica y políticas indigenistas. Quito: Corporación Editora Nacional, 1987. De información extraída de Noticias Secretas de América [1826], Jorge Juan y Antonio de Ulloa añaden que a consecuencia de este mal trato y la falta de alimento, los indios se enfermaban y morían "antes de haber podido pagar el tributo con los jornales de su trabajo." (de Ulloa citados en Corrales 42).
} 
prácticas agrícolas. Los dueños no pudieron hacer nada esta vez. De nada les valieron sus posiciones sociales, sus apellidos o sobornos, porque se comprobó que el terreno era para utilidad pública (Jácome 171). Se puede apreciar la destreza artística del autor que por medio de un hábil retroceso le permite al protagonista regresar al tiempo de la Colonia para hacer un recuento de todos los abusos que han venido sufriendo los indigenas desde aquel tiempo.

Andrés es un personaje complejo, inseguro por pertenecer a dos mundos diferentes: el de los blancos y mestizos y el suyo indígena. En ninguno de los dos vive tranquilo.

No todos los cambios que requiere la vida urbana son negativos. Al contrario, la forzada absorción del español, por ejemplo, le sirve a los indígenas de instrumento indispensable para comunicarse fuera de su "llacta" (terruño) y conseguir integrarse en el mundo socioeconómico nacional. Con el dominio del español, el indio tiene la oportunidad de obtener hasta educación superior, si a así lo desea. Un ejemplo es Andrés Tupatauchi, ${ }^{12}$ el protagonista de Porqué se fueron las garzas es que su educación le permite obtener una carrera, ocupar el puesto de rector en una escuela en Quinchibuela, participar en las actividades del blanco y mestizo y servir de representante de un comité

\footnotetext{
12 Este protagonista tiene en Peguche, Ecuador, una pequeña aldea indígena de Otavalo, Ecuador, un ser real. Su nombre verdadero es Antonio Lema. Habia cursado la universidad en Quito, luego obtuvo una beca para ir a estudiar Antropología Social en los Estados Unidos. Regresó al Ecuador en 1974 casado con una estadounidense. "Esto hace veinte años era una cosa inusitada", dice el autor Gustavo Alfredo Jácome en una entrevista en agosto de 1994.
} 
de derechos indígenas, ante una asamblea indigenista nacional.

La integración indígena al consorcio nacional requiere también de la participación del pueblo para la reconquista de su tierra. Tanto el movimiento indigenista como neoindigenista reconocen el significado vital que tiene la tierra para el indio. Con el propósito de agilitar la devolución de las tierras al indígena, se han promulgado leyes de reforma agraria, se han establecido acuerdos entre el campesinado y los gobiernos, se han creado comités de defensa para los campesinos, pero todavía no se han visto resultados positivos.

Andrés Tupatauchi y los indígenas de su pueblo se dan cuenta que solamente ellos mismos pueden velar por sus propios intereses. Cansados de tanta injusticia deciden formar el comité indigenista Rigcharishu del cual Andrés es el dirigente. Andrés Tupatauchi al igual que Andrés Chiliquinga tiene el don de liderazgo. Incita a sus compañeros a participar en un congreso indigenista nacional y les insiste: "si hay un congreso indigenista, los indios deberíamos estar presentes y hacernos oír, como sea" (Jácome 156). Y así lo hizo. En el congreso en pleno, donde la mayor parte de los representantes no eran indios, pidió la palabra pero se la negaron:

Pero yo soy indio... Con el patrón más inflado le volvió a interrumpir: No puede hablar...Pero señor...Solo quiero solo quiero decir que la suerte que la suerte de los 
indios la resolveremos los indios y no y no los amos indigenistas (Jácome 161).

A pesar que Andrés alcanza solamente a balbucear algo por se le niega la palabra deja sentado el precedente que ahora el indio tiene voz y voto como el blanco y el mestizo. Esta representación del lenguaje fraccionado demuestra no sólo la impotencia del indio frente a sus adversarios, sino también el fraccionamiento de toda una cultura provocada por la dominación colonialista. Pero Andrés y los otros miembros del comité no se detienen por este acallamiento, lucharán además, porque sus madres y esposas no sean objeto de más atropellos. El comité está para protegerlas y hacer justicia y pide además que si las mujeres indígenas tienen que limpiar las calles, de igual manera, las señoras blancas encopetadas tienen que hacerlo. Los indigenas de Quinchibuela ya no esperan que se les haga justicia. Ellos también pueden leer, escribir e interpretar las leyes. Tienen un director educado y profesional capaz de promover una reforma para hacer respetar sus derechos y los de su gente. Los problemas de los indios los resolverán sus propios indios, como dijo Andrés en la asamblea.

Andrés Topatauchi es el líder de la revolución pacifista que persigue la integración indígena a la sociedad nacional, mientras que Andrés Chiliquinga es el líder que da comienzo a la revolución social. El neoindigenismo demanda la participación directa del indígena para su reivindicación, según anotado 
anteriormente. En esta obra, los indios aculturados "se defienden solos y con los métodos legalistas del adversario mismo. Es decir, el indio no se subordina a nadie ya que ha llegado el momento de seguir siendo indio sin aislarse o alejarse del mundo actual" (Handelsman 62).

Este sentido de participación y responsabilidad por parte del indígena, se ve reforzado en el mensaje de Segundo Maiguashca, un indio aculturado, que incita en su libro a sus congéneres a iniciar una campaña sin par por la liberación y rehabilitación del indigenado. Maigashca quiere "gravar en la mente de todos los indios, como un evangelio, la idea de que el indio se salvará por si mismo...mediante la dirección de elementos salidos de su propia raza y la colaboración de todos los que soportan la ominosa situación de parias en nuestra sociedad" (111). 


\section{EXTERIORIDAD E INTERIORIDAD DE LOS PROTAGONISTAS}

\section{La exterioridad de Andrés Chiliquinga}

La critica ha sido injusta con el autor de Huasipungo. Se ha censurado que sus protagonistas son demasiado simples y esquematizados, que son tratados como objetos, como títeres del destino, que carecen de profundidad psicológica. En resumen, la crítica ve a sus personajes retratados como seres amorfos, incompletos, que solamente están descritos desde fuera (Adoum 2324). Quizá es oportuno recordar que no se puede concebir al indio de este periodo "realizando sin dificultad sus valores, en medio de la secular depredación ejercida por el latifundista feudal, el cura y el resto del aparato moral y materialmente represivo" (Cueva 179). Por lo tanto, no es sorprendente que los personajes de Huasipungo aparezcan generalmente "degradado[s]" puesto que son el "Producto histórico de un doble proceso de avasallamiento: el del feudalismo... en declive y el del capitalismo en curso de implantación" (Cueva 179). A pesar de lo expuesto, Andrés Chiliquinga, el protagonista, es un hombre lleno de sentimientos y emociones de amor, dolor, abnegación, fraternidad, y que sabe exteriorizar su frustración e impotencia.

Andrés no tiene reparos en hacer lo imposible por merecer el amor de su mujer y por cumplir sus obligaciones de esposo y padre: roba maíz para 
alimentar a su familia, porque al igual que todos los otros huasipungueros, se moria de hambre. Desentierra la carne del buey que está ya medio podrida, para saciar su hambre y la de su familia. Su patrón había ordenado enterrar al animal que habia muerto en un accidente para asegurarse que "Los indios no deben probar jamás ni una miga de carne. ¡Carajo! Dónde se les dé se enseñan y estamos fregados" (Icaza 116). Roba una vaca del amo para venderla y obtener dinero para poder dar sepultura apropiada a su mujer. Todo lo hace por amor (Sacoto, Novelas Claves 119).

Cunshi muere como resultado de haber comido la carne podrida. La soledad y el dolor que experimenta Andrés ante la muerte de su esposa son tan profundos que siente la necesidad de dialogar, aunque sin recibir respuesta, con el cuerpo inerte de su Cunshi. Entre lágrimas, implora:

- Ay Cunshi, sha ${ }^{13}$

- Ay bunitica, sha

—QQuién ha di cuidar pes puerquitus?

-Pur qué ti vais sin shivar cuicitu

-Ay Cunshi, sha

-Ay bunitica, sha

-Suliticu dejándome, no

13 "Sha: Está allá. Queja para lo que está distante, perdido" (Icaza 161). 
—¿Quién ha de cuidar, pes, al guagua?

-Guagua soliticu...Ayayay...Ayayay... (Icaza 129-130) ${ }^{14}$.

Esta es una escena, casi la más conmovedora y la más patética representación del dolor de Andrés. La habilidad artística de Icaza se comprueba en esta representación de sentimientos hondos expresados por el protagonista en su lenguaje singular, tan solamente suyo.

Finalmente, el protagonista de Huasipungo engendra solidaridad en los suyos. Andrés, el cojo, el indio manavali ${ }^{15}$ despojándose de sus vacilaciones es quien contagia de valor a sus compañeros desamparados. Con el grito ancestral de iñucanchic huasipungo! (la tierra es nuestra) los insta a solidarizarse, a reclamar la tierra que fue de sus mayores. Lucha desesperadamente, sufre extrahumanamente y ama infinitamente. El amor y el dolor de Andrés encuentran solidaridad y refugio en el amor y el dolor de su amante, Cunshi, la mujer de Chiliquinga, sufre en silencio. Sabía que nadie vendría a socorrerla, ni aún en el momento más desesperante y humillante de su vida, cuando el patrón, don Alfonso, la ultrajaba, la violaba, a los pies de la cuna del propio nieto de él. La india calló, pero sintió hondamente pisoteado

\footnotetext{
14 "Puerquitus y boniticu" son los equivalentes a puerquito y bonitica; "cuicitu", diminutivo de cuy. "Shivar" significa callar en el lenguaje popular hablado por los indios. Para una explicación del cambio de vocales en el lenguaje popular, ver nota 16.

15 "Manavafi: Que no vale nada" (Icaza 160).
} 
su honor y el de su marido. Andrés no hubiera podido hacer nada de todas maneras, pero pensó en él con cariño en ese momento de dolor. Debe callar: ¿Gritar? ¿Para ser oída de quién? ¿Del indio Andrés, su marido? '¡Oh! Pobre cojo manavali!', pensó Cunshi con ternura que le humedeció los ojos ... ¿Gritar? ¿Para que le quiten el huasipungo al longo? ¿Para que comprueben las patronas su carishinería?: ¿Para qué...? ¡No! ¡Eso no! Era mejor quedarse en silencio, insensible (Icaza 49) ${ }^{16}$.

De lo expuesto se puede observar que las manifestaciones anímicas de Andrés no pueden provenir de un ser animalizado como se lo ha llegado a conjeturar. Es un ser al que Icaza lo levanta desde abajo para convertirlo en héroe; y un héroe no puede ser un subhombre o un "sujeto paciente" como lo ha tildado Angel F. Rojas (citado en Cueva 106). Los protagonistas de Icaza tal vez no tengan la misma profundidad psicológica que los de Jácome; sin embargo, Icaza trata de penetrar en su interior. Los hace pensar en voz alta, hace que se digan cosas a ellos mismos, o que emitan sus juicios mediante monólogos interiores indirectos. En la siguiente escena, Andrés Chiliquinga se siente abandonado, desolado ante la súbita desaparición de Cunshi. Esta habia sido llevada junto con su hijo y contra su voluntad para servir de nodriza

\footnotetext{
16 "Longo o longa: indio o india joven" (Icaza 160). "carishinería" es un sustantivo que aparentemente es derivado de otro sustantivo quichua "Carishina: Mujer de pocos escrúpulos sexuales. Se desenvuelve como hombre" (Icaza 157).
} 
al nieto de los patrones. Andrés la busca inútilmente; se siente desfallecer, "Su voz se había vuelto suave como una queja, pero en su pensamiento estallaban a ratos ideas tontas, infantiles: 'La guarmi carishina...la guarmi...EI guagua ...¿Pur qué ladu se jueron, pes? ¿Quién les robú? ¿Patrún grande, su merce, $\tan \ldots ?(\text { Icaza } 37)^{17}$.

Otro ejemplo del pensamiento de Andrés, se observa, por ejemplo, en la escena en la que él sirve de guía de la caravana que carga a los amos en sus espaldas. Temeroso de ocasionar un accidente a su amo: "rememoraba las enseñanzas del taita Chiliquinga: "No hay que pisar donde la chamba está suelta, donde el agua es clara...No hay que levantar el pie sino cuando el otro está bien firme...La punta primero para que los dedos avisen... Despacito no más... Despacito" (Icaza 15).

Con el propósito de mantener un equilibrio objetivo de sus personajes, Icaza no se interioriza más en los blancos o mestizos que en los indígenas (Adoum 27). Don Alfonso, por ejemplo, es también un personaje simple, agobiado por las deudas con tiene con su tío, el Arzobispo, los bancos y la Tesorería Nacional, se dice así mismo: "Impuestos. Malditos impuestos. ¿Quién los cubre? ¿Quién los paga? ¿Quién...? ¡Mi dinero! Cinco mil... Ocho mil... No llegan los billetes con la facilidad necesaria. Nooo..." (Icaza 5).

\footnotetext{
17 "Guarmi: Hembra. Hábil en los quehaceres domésticos" (Icaza 159). "jueron" es fueron en la representación del lenguaje popular hablado. Para una explicación del cambio de vocales, ver nota 16.
} 
Sabemos lo que piensa la hija de Pereira de su situación de haber sido burlado su honor por un chagra, por medio de este monólogo interior: ${ }^{18}$ “¡Desgraciado! Si él hubiera querido. ¡Cobarde! Huir, dejarme sola en semejante situación. Fui una estúpida. Yo... Yo soy la única responsable..." (Icaza 14).

\section{La interioridad de Andrés Tupatauchi}

Los personajes de Porqué se fueron las garzas son mucho más complejos que los de Huasipungo. Mientras el protagonista de Icaza es sumamente sencillo, que actúa casi por instinto, un indio relegado al monte, sin voz ni voto, Tupatauchi, el protagonista de Porqué se fueron las garzas es un indio cultivado. Gracias a su educación, ha podido incorporarse al mundo occidental y alcanzar ciertos privilegios de los que gozan solamente los blancos y mestizos. Pero esta nueva posición le enfrenta al rechazo de aquellos y de su propia gente, a la inseguridad en su matrimonio. En su mundo indígena se siente atraído a su pasado. De éste nace una incertidumbre incestuosa que le atormenta sin cesar (Sacoto, Novelas Claves 404).

La figura de Andrés Tupatauchi se nos presenta completa, a través de su niñez, su adolescencia y su juventud y adultez como un ser humano real y pensante y con todos los prejuicios y ambivalencias de la vida urbana

18 "Chagra: gente de aldea. En la capital se les llama así a los que llegan de las provincias" (icaza 158). 
moderna. La vida de Andrés se le complica aún más porque tiene que enfrentarse a los problemas y prejuicios en los Estados Unidos. Su estadía estudiantil en ese país es llena de sorpresas, pero también de muchas inseguridades, a la vez. No entiende si la amistad que le brindan sus compañeros de la universidad es genuina o solamente por curiosidad de su apariencia física tan diferente de la de los blancos, quizá por su timidez, o por compasión de verlo solo. Todo es nuevo para Andrés, hasta las cosas más triviales como las piletas de agua para beber, el secador eléctrico y el dispensador de jabón líquido. Su timidez le prevenia responder a las insinuaciones de sus compañeras. El se daba cuenta que a causa de su inocencia, son ellas quienes deben tomar la iniciativa. Más tarde, reflexiona: "sin saber nada de nada, perdido en un mundo tan complicado, antes tan solo visto por mí en las películas... Yo al principio era tan solo susto y asustado dejaba que hicieran conmigo lo que les venía en gana", dice refiriéndose a sus amigas universitarias (Jácome 22).

Los blancos y los mestizos no podían aceptar que un indio hubiera llegado a ser rector de escuela, dirigente de un comité de liberación indígena, que les tuviera ahora bajo sus órdenes. En todos los lugares frecuentados por los blancos y mestizos se oían insultos como éstos:

El rocoto es insoportable. Le queda viendo a uno, esperando que se le salude. 
Anda como señor el indio verde.

No saluda a nadie

Semejante prosudo, qué va. Emponchado y bajo ese sombrerazo no cede a nadie la acera.

Con decirle que ni a las señoras" (Jácome 46).

A lo largo de la novela se encuentran insultos llenos de prejuicios raciales. Andrés se da cuenta que los mestizos a más de rechazarlo le tienen envidia:

"Hay unos mestizos que no se han conformado con que yo, siendo un natural ${ }^{19}$, haya alcanzado un titulo que ellos qué dezqué. Otros maldisimulan su envidia y me tratan de 'doctorcito', achicando con el diminutivo mi título que les chinga" (Jácome $53)$.

En el siguiente diálogo los mestizos comentan de la profesión de Andrés:

Pero dicen que le han hecho rector de un colegio.

Sí, pero es colegio para indios como él... (Jácome 46).

Y en este otro diálogo, también de mestizos, se observa el rechazo a la autoridad de Andrés por ser indígena: "Vaya usté a tener como superior a un

\footnotetext{
19 "Natural: eufemismo que usa el indio para referirse a sí mismo" (Jácome 327).
} 
rosca ${ }^{20}$, a ser mandado por un indio..." (Jácome 47). Otro ejemplo de discriminación racial se suscita con un chofer que se niega a cederle el paso a Andrés:

El que manejaba —-pensé-, debió quedarse a su derecha...porque yo tengo derecho de vía. Pero no, siguió. Ese es un mestizo - me dije-, conoce tu carro y te quiere hacer un problema...esperó...que retrocediera para dar paso al patrón, pero como yo me mantuve en mi derecho de vía, según él insolentemente, ... comenzó un furioso braceo ordenándome dar retro... (Jácome 78$){ }^{21}$

También los nativos de su pueblo, Quinchibuela, critican la actuación de Andrés. Comentan entre ellos: "Eso $\mathrm{ca}^{22}$ cierto es pes: Ha vuelto vestido como natural mismo, igualito por fuera está, pero cambiaaado por dentro" (Jácome 41). Por otros comentarios que hacen los de Quinchibuela, sabemos que Andrés y su esposa son rechazados por su familia: "Dicen que a gringa no gustó taitas ni hermanos del Andrés. Pero castellanos, racionalotes están pes. Pero son runas, pes. Queriendo el Andrés a gente de Quinchibuela ca, hubra

20 "Rosca, roscón, runa, rutushca: peyorativo de indio" (Jácome 328).

${ }^{21}$ Jácome admitió en la entrevista de agosto de 1994 que este pasaje es una de sus vivencias que le endosa a su protagonista.

22 "Ca: partícula pospuesta que refuerza la expresión" (Jácome 323). 
casado con huarmi de las nuestras pes" (Jácome 42). ${ }^{23}$ Su familia, al igual que la gente de su pueblo se sienten decepcionados que haya roto la tradición de su gente casándose con una extranjera; se negaban a aceptarla "... mantenían la distancia. La observaban, se sonreian con ella, cada vez, pero no acertaban en el trato..." (Jácome 298).

El prejuicio de ser indio le hace dudar a Andrés que pudiera estar casado con una blanca: "Durante mucho tiempo, ya casado, al despertarme y sentir que dormía junto, juntito a mí, me agarraba de ella con miedo de que fiera un sueño... Y como no creía a ratos que soñaba, no quería tocarle por el miedo de que se me desvanezca" (Jácome 11-12). La unión con Karen no es para Andrés Tupatauchi un refugio de amor como lo es para Andrés Chiliquinga y su Cunshi. Al contrario, es un objeto de preocupación y vacilaciones. Karen nunca llega a entender a su esposo, el matrimonio termina en un fracaso.

Andrés trata de asirse a su pasado. En el piensa descubrir su linaje incaico y encontrar la respuesta si su hermana gemela, Mila, podría llegar a ser su esposa legitima como la coya, hermana del inca Atahualpa. Constantemente acuden a él pensamientos incestuosos. En una ocasión mientras estudiaba en los Estados Unidos bajo el efecto del whisky y la marihuana, en medio de una orgía con tres jóvenes americanas, "el cuarto se llena de neblina de

\footnotetext{
23 "Pes: contracción de pues" (Icaza 160); "hubra" es habría en el lenguaje hablado popular.
} 
páramo", Andrés cree ver a la Mila, su hermana que está en el cerro junto a él, "No te vayas Mila no te vayas", pero de pronto vuelve a la realidad y se da cuenta que está con las americanas (Jácome 27). Y cuando está en la intimidad con Karen, su esposa, piensa también en la Mila. A lo largo de la novela, se encuentran otros episodios que sugieren el incesto, el que atormenta al protagonista a pesar de poder justificar en la historia la unión con su hermana de acuerdo a la costumbre incaica.

Basados en éstos ejemplos podemos tener un buen juicio de la personalidad del protagonista porque lo hemos visto desde diferentes ángulos, como profesional, en su vida privada con su esposa, acosado por pensamientos incestuosos con su hermana y como miembro del comité. Andrés Tupatauchi es un indio pensante, consciente de los problemas y prejuicios que le ha ocasionado su aculturación. Su mismo matrimonio con Karen le recuerda que no es igual que los otros indios. Vive en dos mundos: el occidental y el indígena. Quiere integrarse definitivamente al mundo moderno, pero se encuentra discriminado; quiere volver a sus raíces y siente vergüenza. Pasa de un mundo a otro atormentado por su inseguridad. Sin embargo, no llegaremos a descifrar completamente el interior de Andrés Tupatauchi, como tampoco lo pudo hacer su esposa Karen; además, Carlos Mariátegui nos recuerda que: 
La literatura indigenista no puede darnos una versión rigurosamente verista del indio. Tiene que idealizarlo y estilizarlo. Tampoco puede darnos su propia ánima. Es todavía una literatura de mestizos. Por esto se llama indigenista y no indígena. Una literatura indigena, si debe venir, vendrá a su tiempo. Cuando los propios indios estén en grado de producirla' (Mariátegui citado en Cueva 32). 


\section{AUSENCIA HISTÓRICA Y BÚSQUEDA ANCESTRAL}

Muy poco sabemos del origen de Andrés Chiliquinga, excepto que el "taita murió de cólico hace algunos años, la madre vive con tres hijos menores y un compadre que aparece y desaparece por temporadas" (Icaza 19). En el mundo feudal de Huasipungo, el indio es un esclavo, por eso su identidad no es importante. Lo único que le interesa al latifundista es que el indio sea fuerte y capaz de trabajar. Al contrario, para el gamonal, su linaje es muy importante. Automáticamente, su posición social lo coloca en una situación privilegiada. Don Alfonso Pereira, el latifundista, tiene un pariente poderoso, su tío Julio Pereira, un hábil empresario y muy influyente.

Aunque carece de historia Andrés Chiliquinga, el huasipungo para él es muy importante después de su familia. Andrés tiembla ante la sola idea de ser arrancado de su huasipungo: "Si no obedeces te jodes. El patrón te saca a patadas del huasipungo" le grita el mayordomo a Chiliquinga (Icaza 32). En la mente de Andrés hay tres cosas importantes: su Cunshi, su guagua (hijo) y su huasipungo. Por eso cuando regresa a la choza y no encuentra a su mujer ni a su hijo, llama desesperado, en voz alta: "Cunshiiii...Longa bruta...¿Cómo has de dejar, pes, el huasipungo abandonadu...El pobre Andrés Chiliquinga solitu $\tan \ldots$ ?" (Icaza 38). 
Para Andrés Chiliquinga, su conexión ancestral es el poder telúrico que le ata a su huasipungo, que es a la vez parte de su vida. Todos los huasipungueros sienten en su ser esa atracción magnética a su tierra, a la tierra de sus antepasados. Ante la pérdida de sus huasipungos, todos los indios responden al llamado ancestral de "iñucanchic husipungo!" (la tierra es nuestra) y no les importa morir tratando de defender la tierra.

Mientras Icaza excluye toda historia en la vida de su protagonista, Jácome imbuye una rica fuente ancestral en el suyo. ¿¿Quién soy? ¿De quiénes vengo? ¿Dónde encontrar el rastro de mis anteriores pisadas? (Jácome 14), es la constante preocupación de Andrés Tupatauchi. A esta preocupación se añade la ironía que Andrés es profesor de historia, y como tal, se siente impelido a investigar y descubrir su origen incaico. Andrés se enfrenta constantemente a las contradicciones y los problemas de la vida moderna. El nota cambios en su pueblo y en cada uno de sus coterráneos. Trata de entender estos cambios y a su gente pero se encuentra desorientado, confuso. Intenta retroceder a su pasado para descifrar el presente, pero no halla respuesta. Mientras estudia en los Estados Unidos descubre casualmente que podría ser descendiente de los incas:

que el primer hijo de Atahualpa se llamó Topatauchi...que Topatauchi, muchacho todavía en 1533 fue enviado por su padre el inca-shiry Atahualpa, desde Cajamarca a Quito, con una escolta 
de cuatro mil indios, defendiendo al heredero del trono del

Tahuantinsuyo contra el peligro de los viracochas... (Jácome 25).

Aqui comienza la decisión de Andrés de buscar sus raíces y de su razón de ser. Michael Handelsman reconoce tres etapas claves en este proceso. En la primera, Andrés siente vergüenza de ser indio en medio de una sociedad que margina al indígena. El también es marginado, rechazado la primera vez, por una compañera blanca de la escuela. Su dolor es tan grande por la pérdida de ese amor inalcanzable, pero también por el rechazo que sufre. Andrés admite:

allí, terminaron mis ilusiones de perro enamorado de la luna. $Y$ allí comenzó también mi tormento...muchos días sonaron en mis orejas... los insultos: indioemierda erda erda erda, rosca atrevido ido ido ido...me dolía más que nunca haber nacido indio, ser lo que era, un pobre runa, y sin embargo, sentir lo que sentía. Me queria morir (Jácome 37).

Más tarde, esta vergüenza se transforma en orgullo cuando de estudiante en los Estados Unidos descubre, por accidente, que él es posiblemente descendiente de Atahualpa ${ }^{24}$. Andrés lleno de emoción y orgullo comenta sobre sus antepasados:

\footnotetext{
24 "Atahuallpa era considerado como el último señor del Tahuantin-Suyo" (Carrión 35).
} 
pero qué cosas más buenas sobre los incas, qué adelantados habian estado:...trepanaciones, quipucamayos, vírgenes del sol, palacios, ... templos, ... calzada del Cuzco a Quito, el Tahuantinsuyo extendido a los cuatro horizontes del mundo, qué organización del imperio, qué poder, qué riqueza, qué brutal la persona del inca emperador,... Leyendo todo eso, sentia que en mí fermentaba el orgullo de ser indio (Jácome 17).

En la segunda etapa Andrés se dedica de lleno a investigar su pasado y en medio de esto encuentra un libro que describe todas las crueldades que se impusieron a los indios en el tiempo de la Colonia. Aturdido por el dolor de estas injusticias, no sabe si quemar el libro, enterrarlo o hacerle pedazos. Quisiera vengarse, pero el conquistador español ya ha desaparecido. Piensa, luego, en el mestizo que es el continuador infame. Ya no es el encomendero, pero es el hacendado y el mayordomo actuales, y el corregidor es ahora el teniente político, el comisario, el policia o el soldado. Piensa también en el fraile que lo primero que hizo "fue quitarnos la memoria de nuestros dioses buenos, para cambiarnos con un dios terremotero, malgenioso, vengativamente infernal, hecho a imagen y semejanza del blanco" (Jácome 174).

Finalmente, la tercera es una etapa de introspección para Andrés. Se da cuenta que "Ya no sentía que la tierra tuviera esa fuerza de imán que hacía que los otros se pegaran a ella..." como Andrés Chiliquinga y los otros 
huasipungueros lo sentían (Handlesman 65). "Sois un natural desnaturalizado, Andrés Tupatauchi" (Jácome 216). Se siente rechazado por todos. Ya no hay razón de huir al pasado, ni buscar en la historia justificación para tratar de convertir a su hermana gemela en su coya, su esposa. Solamente le queda vivir el presente. En Porqué se fueron las garzas trasciende esta idea fundamental del futuro. Andrés y el resto de quinchibuelenses se transforman en el eje de la maquina del progreso que impetuosa va hacia adelante. Andrés se da cuenta de estos cambios, y que no puede volver al pasado; que éste le es útil solamente en cuanto puede ayudarle a comprender el presente (Handelsman 65). 


\section{EL USO DEL LENGUAJE ESTÁNDAR Y POPULAR}

Para comentar sobre el lenguaje de estas obras, es indispensable remontarnos por un momento al tiempo en que los exploradores llegaron al Nuevo Mundo. Aquí encontraron una rica variedad de habitantes, flora, fauna, etc., e inmediatamente definieron estos elementos desconocidos con palabras españolas. Designaron a las frutas, objetos, lugares y personas extrañas con términos europeos (Fabre-Maldonado 23). Angel Rosenblat admite que Cristóbal Colón usó "vocabulario viejo para nombrar lo nuevo. A las canoas llamó almadías, a los caciques, reyezuelos y al maíz, panizo, etc." (citado en Fabre-Maldonado 23).

A medida que penetraban en territorio americano, los españoles se encontraron con dificultades lingüísticas para definir la geografía; entonces, decidieron adaptar su vocabulario a la topografía y a la fauna que les rodeaban. Por ejemplo: a la puna peruana, la llamaron páramo en el Ecuador. A muchas plantas y animales les dieron nombres europeos por alguna semejanza que vieron en ellos: cedro, nogal, zorro, entre otros (FabreMaldonado 23). "Poco a poco el español de la Peninsula lbérica adquirió diversidad léxica y semántica propia en el Nuevo Continente" (FabreMaldonado 24). Más tarde, con la fusión de las razas indio-española nacen 
palabras mestizas: sustantivos y verbos de raíz española y desinencia india.

Por ejemplo: amu²5 'amo', amitu 'amito', vali 'vale', garuana 'lloviznar', cazarana 'casarse', etc. (Fabre-Maldonado 24). Además, algunos vocablos peninsulares han llegado a formar parte del vocabulario indígena, como: garúa ${ }^{26}$ 'llovizna' y taita 'padre'. De lo expuesto por Fabre-Maldonado en los párrafos anteriores, se puede observar que el lenguaje como medio de expresión de un grupo étnico no es algo estático ni permanente. Evoluciona con el medio ambiente y se adapta a las necesidades de sus miembros.

El lenguaje de Huasipungo y Porqué se fueron las garzas refleja precisamente estos cambios y adaptaciones que el quichua y el español han experimentado desde el tiempo de la Colonia. Para mantener esta autenticidad, los autores de estas obras tratan de ser honestos en la representación del lenguaje indígena, cada uno dentro de su marco histórico y social correspondiente. En Huasipungo, el lenguaje es la expresión del indio subyugado y explotado violenta e inhumanamente por una sociedad feudal sin escrúpulos. Icaza contrarresta esta violencia con un lenguaje también violento, tosco, sin adornos. No desprecia las reglas gramaticales ni el orden de la sintaxis, ni el sentido común, como se le ha acusado, simplemente se rebela

25 "El quichua adolece, en su variedad ecuatoriana, de enorme estabilidad vocálica... las vocales e y o no existen, sólo existen tres: a, u, $I^{n}$. (Toscano Mateus 50-52 citado en FabreMaldonado, 24).

${ }^{26}$ En Murcia y América significa llovizna. Diccionario de la Real Academia Española, 1984. 
contra estos principios porque fuera de ellos encuentra el lenguaje directo, irreverente pero apropiado que va en armonía con la acción turbulenta de su obra de denuncia. Jorge Enrique Adoum no condena esta actitud de Icaza porque considera que "El mismo orden que impone "un estado de cosas real y espantoso' pretende imponer a los escritores su gramática, su sintaxis, su estilo" (28). Adoum además denuncia a los críticos disciplinarios, a quienes les considera como policias de la lengua porque no toleran la libertad del escritor de escoger una gramática y una sintaxis apropiadas para lo que tienen que decir.

A diferencia de Huasipungo donde el lenguaje no alcanza a desarrollarse por el grado intelectual elemental de los protagonistas indigenas y principalmente porque en el tiempo histórico de Huasipungo de los años treintas:

no era cuestión de romper con la escritura burguesa... sino de emprender la gran tarea de forjar una lengua literaria nacional: esa lengua, como la cultura nacional toda, mal podía surgir definitivamente decantada y sin contradicciones de la noche a la mañana (Cueva 171).

En Porqué se fueron las garzas el protagonista es un hombre libre, educado y profesional que habita en una zona urbana en la década de los '70. Tiene completo dominio del quichua, el español y puede comunicarse también 
en inglés. En esta época, los escritores neoindigenistas ya pueden experimentar con el lenguaje dentro de la literatura. Jácome es uno de estos escritores que sabe aprovechar las técnicas innovadoras de la nueva narrativa, especialmente, a nivel del lenguaje, y ha podido introducir uno más natural que es la representación auténtica de la sociedad que presenta en su novela. Se observa una exhibición de los diferentes tonos lingüísticos propios de cada personaje y también de expresiones regionales populares: "Usé muchas expresiones otavaleñas que recordaba haber oído en boca de mi madre", admite Jácome.$^{27}$ Este escritor, como Icaza, tampoco es un humilde seguidor de las reglas gramaticales o la sintaxis. No se conforma con lo tradicional. Es un innovador, un creador y un artífice de la lengua como veremos en algunos ejemplos posteriormente.

Si por complacer a los críticos, se pretendiera cambiar el lenguaje crudo de Huasipungo con uno más refinado y compatible con el oído de los puristas; y la gramática y la sintaxis de esta novela y Porqué se fueron las garzas con unas que pudieran contentar a los tradicionalistas, Huasipungo perdería la fuerza expresiva y el sello denunciador que Icaza quiso imprimir en ella y en Porqué se fueron las garzas se restaría la autenticidad de que está

${ }^{27}$ Gustavo Alfredo Jácome nació en Otavalo, Ecuador en 1912. Situada a unos cien kilómetros más o menos, al norte de Quito, Otavalo es una población indígena muy pintoresca, muy progresista e internacionalmente conocida por su famoso mercado de artesanías. En agosto de 1994, la autora de esta tesis, también ecuatoriana, tuvo la oportunidad de entrevistar a este autor en Quito. 
impregnada esta novela. "En el fondo, sería un intento de sofocar y de reprimir una rebelión verbal contra el 'orden' de la gramática y el 'sentido común' del estilo" propone Jorge Enrique Adoum (29). Posiblemente, acabariamos frente a una estilizada e inverosímil Cumandá, donde el lenguaje indígena nada tiene que ver con el habla conversacional de los indios del Oriente ecuatoriano. Por ejemplo, el diálogo entre Tongana, padre adoptivo de Cumandá y jefe de los jibaros y Yahuarmaqui, gran curaca de la temida tribu de los paloras y futuro esposo de la hija de Tongana, ilustra este caso:

-Entre tus amigos me cuento también yo... ¡Oh, hermano Yahuarmaqui! ha llegado el momento en que necesito tu protección: tú eres la paima grande y yo la palma chica - Hermano,... los días de fiesta no son días de castigo, ya lo sabes; ¿queréis, por ventura, que los genios benéficos se enojen con nosotros? (106).

Esta y el resto de las conversaciones indígenas en Cumandá tienen este sabor español netamente peninsular, completamente ajeno a la realidad lingüística de los nativos. En Huasipungo y en Porqué se fueron las garzas se ha superado este problema. Sus autores han optado por representar el habla popular y el habla estándar como representaciones auténticas de las sociedades que describen en sus obras. Estándar, en este caso se refiere al español de la sociedad en general, excluyendo el quichua. En el popular se 
incluye el quichua que es ya modificado por la influencia del español y viceversa. Es usado por los protagonistas indígenas y por otros personajes como el chagra ${ }^{28}$ y el cholo ${ }^{29}$ en las dos novelas.

Lo singular de Icaza frente a otros escritores, es que su lenguaje escrito refleja el hablado. Aún en las narraciones o comentarios en los que usa el lenguaje estándar, trata de evitar todo lo que tenga la apariencia de lenguaje cuidado, elegante, distante de la realidad humana que trata de plasmar. "Por eso huye de toda expresión lingüistica que pudiera denunciar una lejanía entre el autor y su mundo" (Corrales, J. Icaza 61). Por ejemplo, en la siguiente narración se descubre una ruptura de la afinidad de tiempos ${ }^{30}$ que a más de ser una característica del lenguaje estándar, se convierte en un rasgo lingüístico muy efectivo:

En la mente de los indios -- los que cuidaban los caballos, los que cargaban el equipaje, los que iban agobiados por el peso de los patrones -- ,en cambio, sólo se hilvanaban y deshilvanaban ansias de necesidades inmediatas: que no se acabe el maíz

\footnotetext{
28 "Chagra: Gente de aldea. En la capital se les llama asi a los que llegan de las provincias" (Icaza 158).

29 "Cholo: Mestizo de indio y blanco" (Icaza 158).

${ }^{30}$ Según Humberto Toscano, en la Sierra ecuatoriana y en otras regiones sudamericanas casi ha desaparecido el imperfecto del subjuntivo por el influjo del quichua (citado en Corrales, Jorge Icaza 63).
} 
tostado, o la mashca (harina de cebada), del cucayo ${ }^{31}$, que pase pronto la neblina para el fin de la tembladera, que sean breves las horas para volver a la choza, que todo en el huasipungo permanezca sin lamentar calamidades... que los amos que llegan no impongan órdenes dolorosas e imposibles de cumplir, que el agua, que la tierra, que el poncho, que la cotona... (Icaza 14).

En el ejemplo que acabamos de exponer, la discordia en la afinidad de tiempos se refiere a los siguientes verbos: "acabe", en lugar de acabara o acabase; "pase" por pasara o pasase; "sean" por fueran o fuesen. A pesar de la ruptura de los tiempos mencionados, las expresiones en presente provocan una reacción inmediata en el lector porque denotan cercania y actualidad que es lo que Icaza se propone conseguir en su relato. (Corrales, Jorge Icaza 62). Este segundo ejemplo también es una demostración de la ruptura de correlación de tiempos verbales:. El primer favor del párroco fue hacer que Pereira compre la parte de los hermanos Ruata - dos chagritos huérfanos de padre y madre... (Icaza 23). En el ejemplo citado, la distensión de tiempos se refiere a "compre", en lugar de comprara o comprase y su empleo surte el mismo efecto que el del ejemplo anterior, reacción inmediata en el lector. Otro rasgo del lenguaje estándar es la inclusión de vocablos quichuas en la narración, como ilustra el siguiente ejemplo de Huasipungo:

31 "Cucayo: Comestible que se lleva en los viajes" (Icaza 157). 
Con el mismo pilche, generosamente, uno tras otro, Tancredo Gualacoto repartió el guarapo. Al final, agarró el azafate con ambas manos y bebió de una vez la sobra del brebaje. Luego pidió otros cuatro reales. Tenía que cargarse coraje, tenía que tomar fuerzas, para ir a donde el señor cura a pedirle una rebajita en los derechos de la misa (lcaza 96).

Con la presencia de las palabras quichuas en el lenguaje estándar como "pilche" (recipiente hecho de la mitad de una media calabaza) y "guarapo" ("jugo de caña de azúcar fermentado. Bebida con la cual se emborrachan los indios" (Icaza 159) y también de las expresiones coloquiales como: cargarse de coraje (armarse de valor), taita cura (sacerdote), una rebajita (un pequeño descuento), Icaza demuestra, una vez más, no sólo su conocimiento de la jerga estándar, pero también su acercamiento a la cultura que describe aquí. Por lo tanto, le imbuye más credibilidad a la obra.

En el caso de Jácome, no sólo introduce vocablos quichuas en la narración, pero también manipula el lenguaje hábilmente, como se puede observar en el siguiente ejemplo: "El indio achaguarquerado, asimismo con la cabeza enflorada, hizo un ruido de comienzo de risa que se quedó en la garganta, como que intentara reírse amargamente de su suerte" (Jácome 77). 
Es muy interesante como el autor convierte el sustantivo chaguarquero ${ }^{32}$ en el adjetivo "achaquarquerado", y asi logra dar una descripción muy pictórica y a la vez muy local. En la siguiente descripción también se introducen vocablos quichuas y además expresiones muy regionales:

Chaquiñan abajo, cerca de la laguna, estaba la choza del Tibucio Tocagón, tejedor de esteras. Su hijo menor se llamaba José. Seis años tenía el Jusico en sus cachetes requemados por la tostadura del frío madruguero, pero desde los dos gorjiaba vivo vivo en su quichua. Como locro nomás le hervía la boca al Jusico (Jácome 83).

Esta narración está saturada de un sabor típico de la jerga nacional estándar de la Sierra ecuatoriana: "chaquiñan", camino de a pie (Jácome 324); "esteras", tejido firme de esparto que los indígenas ponen en el piso para acostarse en él; "gorjiaba" denota el reemplazo de la i por la e que no existe en el quichua del Ecuador según explica Humberto Toscano (citado en FabreMaldonado 24); finalmente, "vivo vivo" también es una expresión popular usada en lugar de soltura. El lenguaje del mundo narrado se enriquece con símiles, elementos líricos y metafóricos e imágenes, entre otros. En algunos

\footnotetext{
${ }^{32}$ Chahuarquero: nombre genérico de cualquier tronco de árbol, muy delgado, irregular y de color café obscuro que usan generalmente los indígenas como base para hacer sus chozas. Posiblemente es una combinación de palabra quichua "chahuar" que significa cabuyo, penco. Diccionario Kichua-Castellano Yurakshimi-Runashimi de Gauco Torres de Fernándes de Cordova. Cuenca, Ecuador: Casa de la Cultura Ecuatoriana, Núcleo del Azuay, 1982.
} 
casos, éstos sirven para suavizar escenas eróticas o incestuosas del protagonista con su esposa, Karen o con su hermana, Mila (Sacoto 427). Por ejemplo, su origen indio hace que Andrés se sienta inferior ante su esposa americana; a veces, creía que soñaba cuando estaba junto a ella y no queria tocarla por que tenia miedo que se le desapareciera, pero "Poco a poco, según mis manos se iban haciendo de confianza, me daba gusto de acariciarle como en una sola mazorca" (Jácome 12). El valor del lenguaje narrativo está en que el autor ha sabido escoger términos muy significativos dentro del mundo natural que describe: "mazorca" es el alimento básico del indio. Al compararlo con el cuerpo de la mujer produce un efecto sinestético casi completo; recrea la vista, el tacto, el gusto, el olfato. Esta otra escena sensual se encuentra matizada por hermosas imágenes: "Y porque siento a mi lado el tibio oleaje de Karen... estaba pegadita a mí, blanca, sedita, con ese olor de hembrísimaricura" (Jácome 11). Tanto Jácome como Icaza tratan de moldear el español a la pronunciación quichua propia del mundo que describen. En Porqué se fueron las garzas se observa, además, riqueza y habilidad en el manejo de la lenguaje; en las dos obras se puede apreciar el intento de sus autores de proporcionar autenticidad a sus obras.

Los comentarios que hace el autor de Huasipungo a lo largo de esta novela, también representan el uso del lenguaje estándar. En la mayoria de los casos lo hace de una manera inconspicua, valiéndose del paréntesis que es 
uno de sus rasgos peculiares. Manuel Corrales Pascual se atreve a concluir que el paréntesis es un rasgo estilístico de Icaza por el gran número de veces que lo ha encontrado repetido en la novela, más de seiscientas cincuenta, en la obra que consta de ciento cincuenta y seis páginas solamente. El paréntesis puede ser una palabra, un sustantivo, un adjetivo, o un adverbio; dos o más sustantivos o adjetivos, o una frase completa, escritas junto a la narración principal para hacer aclaraciones, juicios y apreciaciones, etc. El paréntesis es generalmente breve, preciso, sarcástico, informativo (Corrales, Jorge lcaza 37, 43). En Huasipungo, aparecen generalmente entre guiones o entre comas, por ejemplo:

1. Ráfagas de viento - helado, cortante-, arremolinándose "sobre el campo de la minga... (Icaza 73).

2. En pocas semanas don Alfonso Pereira, acosado por las circunstancias (Icaza 10).

3. arregló cuentas y firmó papeles con el tío y Mr. Chapy... Y una mañana de los últimos dias de abril salió de Quito con su familia -esposa e hija- (Icaza 10).

4. Ni los parientes, ni los amigos, ni las beatas de la buena sociedad capitalina se atrevieron a dudar del motivo económico, puramente económico, que obligaba a tan distinguidos personajes a dejar la ciudad (Icaza 10). 
5. Desde la capital, con la presteza con la cual las autoridades del Gobierno atienden estos casos, fueron enviados doscientos hombres de infanteria a sofocar la rebelión (Icaza 152).

El primero es un ejemplo de paréntesis integrado por dos adjetivos que sirven para calificar viento. En el segundo, tercero y cuarto ejemplos, los paréntesis sirven para hacer aclaraciones de diferente índole. La segunda aclaración se refiere al estado de ánimo de Pereira. La tercera sirve para especificar, y la cuarta, para acentuar el contenido del juicio que los conocidos de Pereira se hacen del motivo del viaje a la hacienda. En el último, formado por una frase entera, el autor critica sarcásticamente la intervención del Gobierno. Con los ejemplos citados se ha ilustrado la efectividad del paréntesis breve, preciso, sarcástico, con el cual el autor trata de llamar la atención del lector. Este se ve obligado a pausar para considerar el contenido de cada paréntesis en el que el autor está emitiendo sus comentarios. Sin el paréntesis la narración resultaría demasiado simple y no se apreciaria ninguna peculiaridad del autor.

Los comentarios que hace Jácome en Porqué se fueron las garzas también son en lenguaje estándar como en Huasipungo; sin embargo, Jácome inserta en sus comentarios vocablos locales. En el siguiente ejemplo, el autor comenta acerca de la Mila: "¿Quién lloraba al Andrés? ¿Era la hermana a quien dolía la separación quizá definitiva del ñaño porque ya casado con 
gringa se quedaria para siempre en los Estados?" (Jácome 61). En el Ecuador, "ñaño significa hermano, pero también se usa ñaña ${ }^{33}$, hermana; "los Estados", se refiere exclusivamente a los Estados Unidos de América. En el siguiente comentario, el autor incluye términos regionales: "Cuando confesaba a las maltonas y a las hijas de Maria se tardaba más y salia del confesionario coloradote y con las orejas rocotiándole" (Jácome 121). En la Sierra ecuatoriana "maltonas", se refiere a las jóvenes adolescentes; se usa también en masculino y para referirse al tamaño de ciertos animales, entre ellos al cerdo. La palabra "rocoto" es posiblemente un derivado de rocote ${ }^{34}$. En el Ecuador se usa como peyorativo de indio, o para comparar algo o alguien con el color rojo intenso del rocote: Pero el autor no se contenta solamente con este sustantivo, lo convierte en verbo progresivo para darle un efecto más actual. Hasta aqui se ha ilustrado el uso del lenguaje estándar utilizado por el narrador omnisciente y para los comentarios del autor en las dos novelas. Luego, tenemos el uso del lenguaje popular.

Popular es el lenguaje usado por el protagonista y otros personajes indios en Huasipungo y Porqué se fueron las garzas. Si partimos de la premisa que el lenguaje es la expresión de una cultura, se hace imposible separar

\footnotetext{
${ }^{33}$ En Chile, ñaña significa hermana mayor solamente. Diccionario de la Real Academia, 1984 34 "Rocote: planta y fruto de una especie de aji grande, de la familia de las solanáceas" . Diccionario de la Real Academia, 1984.
} 
estos dos elementos. En el caso de los protagonistas indígenas de Huasipungo y Porqué se fueron las garzas, su lenguaje es la expresión dualista de la cultura indígena fragmentada, sofocada por la blanca; es el quichua españolizado o el español "quichuizado"35.

Huasipungo, por ser una novela de carácter realista, su autor trata de ser lo más fiel al habla indígena y al realismo que su obra demanda.

Refiriéndose al periodo de la novela realista, Jorge Enrique Adoum comenta que el autor latinoamericano "hacia hablar a sus personajes en la jerga popular" (citado en Cueva 170). Agustín Cueva explica que el uso de esta jerga no es una cuestión solamente de folklore, sino que es uno de los elementos lingüísticos determinantes alcanzados por el realismo social (170). Siempre que los indios hablan en Huasipungo, el autor procura "transcribir incluso rasgos fonéticos peculiares. No digamos de las construcciones impregnadas de sabor quichua, o expresadas en un español rudimentario" (Corrales, Jorge lcaza 61). En el siguiente ejemplo, los indios aunados en dolor y rebeldia, pero llenos de esperanza se dirigen a Andrés Chiliquinga cuando van a ser despojados de sus huasipungos:

- ¿Qué haremus, caraju?

-¿Qué?

\footnotetext{
${ }^{35}$ Mi término.
} 
- ¿Cómu?

- ¡Habla nu más, taiticu Andrés!

- ¡Deci, pes!

- ¿Nus arrancarán así nu más de la tierra?

-Nus arrancarán comu hierba manavali.

-Comu perro sin dueñu (Icaza 149).

En este ejemplo se puede apreciar el afán que tiene lcaza de imitar el lenguaje y la pronunciación de sus personajes para ofrecernos una realidad más plausible del mundo indígena que describe. Se puede observar el reemplazo de la u por la o en "Cómu, nu, taiticu, nus, nu, comu dueñu", convirtiéndose asi en un español modificado por la influencia del quichua según indica Humberto Toscano que "en el quichua del Ecuador las vocales e y o no existen, sólo existen tres: a, u, i,". Por eso los indios cuando hablan español tienden a cambiar la e en i y la o en u. (citado en Fabre-Maldonado 24). "nu más" (no más), citada arriba, es una expresión muy popular, usada frecuentemente en el Ecuador. Parece que implica la idea de subordinación a la autoridad; por ejemplo, se dice siga no más, sírvase no más; en lugar de decir, siga o sírvase, está bien, o continúe; "pes" (pues), se ha vuelto una 
contracción por la reducción del diptongo ue; "caraju" (carajo) ${ }^{36}$ también esta palabra denota el reemplazo de u por la falta de la o en el quichua. Con el empleo de esta palabra irreverente, el autor refleja la personalidad tosca del personaje; "manavali" (no vale nada), pertenece al grupo de compuestos, mitad quichua, mitad mestizos (Carlos Alvarez Pazos citado en FabreMaldonado 24). También la incorporación de vocablos indígenas en un contexto español es común en el lenguaje popular indígena. Por ejemplo: "¿Tienes bastante leche? -Arí niña, su mercé." (Icaza 26). Finalmente, las expresiones quichuas, son las que confieren a esta obra un sabor autóctono. He aqui el grito calcinante: "iñucanchic huasipungooo!, ¡ñucanchic huasipungo!" (la tierra es nuestra), que es el llamamiento ancestral, impregnado de una fuerza telúrica que solidariza a los indios en ese momento de dolor desgarrante, cuando les usurpan sus huasipungos. El quichua es la lengua propia de los indios y solamente ellos pueden entenderla y sentirla profundamente. No importa que su tierra y su honor se les haya quitado, pero su lengua se mantiene invencible, "La palabra no ha sido vulnerada porque estaba aparte, y más allá [de la tierra] de la piedra y de la selva. Se desgranaba eternamente en el reino de los sonidos puros" (Chang-Rodríguez 486).

\footnotetext{
36 "Pene, miembro viril. Es voz malsonante. Usase como interjección" Diccionario de la Real Academia Española, 1984. Las interjecciones ¡caracho!, ¡caramba! o ¡caray! se usan generalmente como eufemismos de carajo.
} 
El lenguaje popular que usa Icaza para hacer hablar a sus personajes indígenas refleja no sólo la personalidad de éstos sino también, la rebelión contra de las normas feudales. Para denunciar las atrocidades que se cometen contra los indios no podia estar escrito en un estilo conceptual ni refinado. Todo lo contrario su tono es violento, áspero, truculento, porque quiere indignar al lector y despertar las conciencias de quienes puedan buscar una solución a la situación monstruosa del indio. Finalmente, si lcaza rechazara este lenguaje, estaría renunciando a su derecho de la libre representación del arte. A pesar de que el tema es desconcertante y la trama, una tragedia de las más dolorosas, el autor consigue imbuirle en la obra algo de lirismo. En el ejemplo ya citado que ilustra los sentimientos de dolor de los protagonistas, la queja de Andrés ante el cadáver de su esposa es como una plegaria : "- Ay Cunshi, sha. - Ay bunitica, sha..." (Icaza 129-131). Aunque "monocorde", como dice Sacoto, este fragmento es una expresión de dolor y de dulzura a la vez.

En Porqué se fueron las garzas el lenguaje popular es usado por el protagonista y los demás los personajes indígenas, en lo que al español y quichua se refiere, porque Andrés Tupatauchi puede comunicarse también en inglés. Se ha mencionado que una de las razones porque el lenguaje de los personajes de Huasipungo aparece elemental se debe al nivel intelectual de sus personajes indígenas, agravado por el sistema feudal. Casi medio siglo ha transcurrido entre los escenarios socioeconómicos y políticos de estas dos 
novelas. En el tiempo histórico de Porqué se fueron las garzas casi ha desaparecido el feudalismo y el indio llega a las zonas urbanas; necesita aprender el español y también educarse para poder sobrevivir en la ciudad. En el caso de Porqué se fueron las garzas, su protagonista principal ha conseguido, además, educación superior. Por lo tanto, Jácome y el resto de escritores indigenistas responden a la necesidad de introducir un lenguaje compatible con la realidad moderna de este protagonista indigena. Andrés Tupatauchi se expresa constantemente en español, su segunda lengua, con palabras intercaladas de su quichua nativo. Asi se expresa en el siguiente monólogo interior:

Así siento más que es mi mujer, cuando me da de comer lo que ella cocina para mí y cuando después del baño me trenza el guango $^{37}$. Entonces, Andrés Tupatauchi, hasta te inflas. En esos ratos, qué bien que te queda eso de 'indio togado' (Jácome 14). El insertar palabras quichuas en el español y usar vocablos regionalistas, le confiere al lenguaje más verosimilitud. Con este segundo ejemplo se corrobora el deseo del autor de ofrecernos una obra verosímil:

Para los demás yo era pura soledad de páramo, puro silencio de niebla, molino dando vueltas y vueltas sobre lo mismo. Pero otros

\footnotetext{
37 "Guango: cabellera trenzada" (Jácome 325).
} 
días y otras noches, Shunsho ${ }^{38}$ Andrés Tupatauchi, muspa ${ }^{39}$ Andrés Tupatauchi, soñándote semejantes cosas, loco mismo croque ${ }^{40}$ estás Andrés Tupatauchi (Jácome 18).

Por los ejemplos anotados, se puede concluir que el lenguaje popular entre las dos novelas difiere en el grado de desarrollo de la lengua misma, las dos guardan la sapidez del quichua, pero el lenguaje de los personajes de Porqué se fueron las garzas es infinitamente más inteligible que el de Huasipungo. Finalmente, las palabras inglesas salpicadas en la novela permiten reconocer a esta obra el carácter internacional que tiene. Veamos algunos ejemplos: "No barbas, no impulso varonil con las girls, no boy-friend de ninguna... En los weekend era invitado a una y otra parte" (Jácome 21). El mundo lingüístico de Andrés se va complicando como todos los aspectos de su vida. El narrador comenta: "En la intimidad hablaban en inglés. A ratos, él se pasaba al castellano, pero desvariar desvariaba en quichua y en quichua conversaba con la Mila" (Jácome 163). Si un rasgo del indigenismo es reconocer el lado humano de los personajes, Jácome respeta ese principio porque actúa con honestidad cuando le permite al protagonista expresarse en

\footnotetext{
38 "Shunsho: tonto" (Jácome 329).

39 “Muspa: tonto" (Jácome 327).

40 “Croque: contracción de creo que.
} 
sus diferentes idiomas. Además, la diversidad de lenguas confiere a la novela universalidad y autenticidad. Sin la inserción del quichua mermaria lo genuino de la expresión de Huasipungo y en Porqué se fueron las garzas y se faltaría a la verdad. Según dice Raquel Chag-Rodríguez: "Porque la palabra es la encarnación de la verdad, porque el lenguaje tiene significado" (486). 


\section{CONCLUSIÓN}

Hemos visto que el tratamiento de los protagonistas en Huasipungo y Porqué se fueron las garzas es diferente a pesar de que el propósito reivindicatorio del indio es común en las dos obras. Andrés Chiliquinga, protagonista de Huasipungo, pertenece a una sociedad feudal encabezada por el latifundista Pereira secundado por el teniente político y el cura -- la trilogía del aparato social -- que mantiene a Chiliquinga en un completo estado de servidumbre y explotación hasta convertirlo en un ente infrahumano.

Chiliquinga no sólo pierde su libertad, pero también su huasipungo, su tesoro más preciado, después de su familia. Icaza, un autor comprometido, denuncia sin miedo la opresión y la crueldad con que es tratado el indio. Describe fielmente la vida angustiosa del indio con toda crudeza, sin omitir los detalles por morbosos que parezcan. Su propósito es concientizar al lector y a quienes puedan contribuir a solucionar este gran problema que es una lacra social. Icaza logra este propósito gracias a su estilo realista, suculento. Despojado de todo adorno presenta en vivo el sufrimiento del indio. La denuncia lo refuerza con un lenguaje directo, tosco, violento, irreverente, pero que refleja la realidad del mundo social que desea presentar (Cueva 108).

Andrés Tupatauchi, a diferencia de Chiliquinga, es miembro de una sociedad urbana. Logra integrarse a la cultura occidental, pero en este 
proceso se enfrenta a un mundo lleno de prejuicios y complejos. Tupatauchi representa al hombre moderno, pensante, sensible, con preocupaciones existenciales. Su búsqueda ancestral es su continua preocupación y su razón de ser. Se siente orgulloso de su pasado, trata de mantenerse en contacto con él y a la vez de adaptarse a las demandas de la vida moderna que lo marginan. Tupatauchi oscila constantemente entre su cultura indígena a la que se aferra con orgullo y la de los blancos y los mestizos, que tanto odia. Reconoce que es diferente de los otros indios y por eso sufre el rechazo de la gente de su pueblo y de su propia familia. Es un ser acomplejado, atormentado, pero que transciende el estereotipo del realismo superficial en el que se le ha sumido a Chiliquinga; sin embargo, Topatauchi sigue hermético como Chiliquinga, a pesar de haberse integrado al mundo occidental, pero Jácome trata de describirlo desde dentro. "Los silencios del indio no son vacios, deben ser rellenados...con algún contenido espiritual, y eso convertí yo en soliloquios o en monólogos, aprovechando estos silencios del indio" ${ }^{41} \mathrm{El}$ lenguaje de Jácome, al igual en que el de Icaza, logra reflejar el sentir del pueblo indígena y el del resto de las sociedades que describen en sus novelas. Además, las frases en inglés que usa Topatauchi le confirman como un indio moderno en vía de integración internacional.

\footnotetext{
${ }^{41}$ Comentarios que hizo Jácome en la entrevista de agosto de 1994
} 
Por todo lo expuesto, se puede observar que el propósito reivindicatorio en las dos novelas tiene un enfoque diferente. En Huasipungo el punto de vista es institucional porque considera que la reivindicación del indio se encuentra en el cambio o abolición de las instituciones, como el feudalismo. En Porqué se fueron las garzas, se presta atención a la sociedad, pero al mismo tiempo, se da importancia a la esencia cultural indígena que es parte esencial de los individuos. Sin embargo, en ninguna de las ellas hemos llegado a conocer verdaderamente al indio porque la narrativa es "todavía una literatura de mestizos... Una literatura indígena, si debe venir, vendrá a su tiempo. Cuando los propios indios estén en grado de producirla" (Mariátegui citado en Cueva 173). 


\section{BIBLIOGRAFÍA}

Adoum, Jorge Enrique. "Huasipungo: El indio, persona, o personaje." Casa de las Américas 22.127 (1981): 22-24.

Alarcón, Jorge. Eva Giberti, Bernard Dulcey, José González Poyatos S.E., Teodoro Sackett y Francisco Ferrandiz Alborz. Literatura Icaciana. Quito: Offset Ecuador, 1977.

Alegría, Ciro. El mundo es ancho y ajeno. México: Editorial Diana, 1960. Arguedas, José María. Los ríos profundos. Santiago, Chile: Editorial Universitaria, 1967.

Asturias, Miguel Angel. Hombres de maíz. Madrid: Alianza Editorial, 1972. Carrión, Benjamín. Atahuallpa. Quito: Editorial Ecuador, 1992.

Castellanos, Rosario. Oficio de tinieblas. México: Editorial Joaquín Mortíz, 1962.

Cometta Manzoni, Aída. El indio en la novela de América. Buenos Aires: Editorial Futuro, 1960.

Cornejo Polar, Antonio. "Para una interpretación de la novela indigenista." Casa de las Américas 100 (1977): 40-48.

---. La novela peruana. Lima, Perú: Editorial Horizonte, 1989. 
Corrales, Manuel. "Las raíces del relato indigenista ecuatoriano." Revista de crítica literaria latinoamericana 4.7-8 (1978): 39-52.

--. Jorge Icaza: Frontera del trabajo indigenista. Quito: Centro de Publicaciones de la Pontificia Universidad Católica del Ecuador, 1974. Cueva, Agustín. Lecturas y Rupturas. Quito: Editorial Planeta del Ecuador, 1986.

Chang-Rodríguez, Raquel. Voces de Hispanoamérica: Antología Literaria. Boston: Heinle \& Heinle Publishers, 1988.

Chaves, Fernando. Plata y bronce. Quito: Editorial Ecuador, 1993.

Chiriboga O., Leonardo. "El problema del indio examinado desde el punto de vista de la organización militar." Imprenta del Ministerio de Gobierno de Quito (1938): 19-71.

Diccionario de la Real Academia de la Lengua Española. 1984.

Fabre-Maldonado, Niza. Americanismos, indigenismos, neologismos y creación literaria en la obra de Jorge Icaza. Quito: Abrapalabra Editores, 1993. Gómez-Gil, Orlando. Historia crítica de la literatura hispanoamericana. New York: Holt, Reinehart and Winston, 1968.

Handelsman, Michael $\mathrm{H}$. "Algunas acotaciones sobre el neoindigenismo de Porqué se fueron las garzas." Explicación de textos literarios 12.1 (198384): 59-66.

Icaza, Jorge. Huasipungo. Bogotá: Editorial La Oveja Negra, 1985. 
Jácome, Gustavo Alfredo. Porqué se fueron las garzas. Barcelona: Editorial Seix Barral, 1980.

López y Fuentes, Gregorio. El indio. New York: W.W. Norton \& Company, 1940.

Llorente Medina, Antonio. "Intertextualidad y Mito en Porqué se fueron las garzas de Gustavo Jácome." Revista Iberoamericana 58.158-159 (1992): 449-463.

Maiguashca, Segundo B. El indio cerebro y corazón de América. Santo Domingo de los Colorados, Ecuador: Segundo B. Maiguashca A., 1991. Marcos, Juan Manuel. "La ternura pensativa de José María Arguedas." Revista Iberoamericana L.127 (1984): 445-457.

Mera, Juan León. Cumandá o un drama entre salvajes. Quito: Editorial Don Bosco, (sin fecha).

Muñoz, Braulio. "José María Arguedas Indio de Corazón." Américas mayojunio 1982: 25-29.

Orbe Rubio, Gonzalo. Los indios ecuatorianos: evolución histórica y politicas indigenistas. Quito: Corporación Editora Nacional, 1987.

Paz, Octavio. El laberinto de la soledad. México: Fondo de Cultura Económica, 1959.

Ribadeneira, Edmundo. La moderna novela ecuatoriana, Quito: Editorial Universitaria, 1981. 
Rodriguez-Luis, Julio. "El indigenismo como proyecto literario: Revaloración y nuevas perspectivas." Hispamérica 55 (1990): 41-50.

Sacoto, Antonio. "Algunas consideraciones sobre el neoindigenismo ecuatoriano." Discurso Literario: Revista de Temas Hispánicos 6.1 (1988): 245-253.

--.."La novela ecuatoriana del '70." Cuadernos Americanos 3 (1980).

---. La nueva novela ecuatoriana. Cuenca, Ecuador: Publicaciones del Departamento de Difusión Cultural de la Universidad de Cuenca, 1981.

---. Novelas claves de la literatura ecuatoriana. Cuenca, Ecuador:

Publicaciones del Departamento de Difusión Cultural de la Universidad de Cuenca, 1992.

---. El indio en el ensayo de la América española. Cuenca, Ecuador: Casa de la Cultura Ecuatoriana, Núcleo del Azuay, 1988.

Salazar Bondy, Sebastián. "Evolución del llamado indigenismo." Sur marzoabril 1965: 45-50.

Sommers Joseph. "The Indian-Oriented Novel in Latin America: New Spirit, New Forms, New Scope." Journal of Inter-American Studies 6.2 (1984): $249-265$. 